University of Nebraska - Lincoln

DigitalCommons@University of Nebraska - Lincoln

Faculty Papers and Publications in Animal

Science

Animal Science Department

August 2001

\title{
Direct and correlated responses to two-stage selection for ovulation rate and number of fully formed pigs at birth in swine
}

\author{
A. Ruiz-Flores \\ University of Nebraska-Lincoln \\ R. K. Johnson \\ University of Nebraska-Lincoln, rjohnson5@unl.edu
}

Follow this and additional works at: https://digitalcommons.unl.edu/animalscifacpub

Part of the Animal Sciences Commons

Ruiz-Flores, A. and Johnson, R. K., "Direct and correlated responses to two-stage selection for ovulation rate and number of fully formed pigs at birth in swine" (2001). Faculty Papers and Publications in Animal Science. 99.

https://digitalcommons.unl.edu/animalscifacpub/99

This Article is brought to you for free and open access by the Animal Science Department at DigitalCommons@University of Nebraska - Lincoln. It has been accepted for inclusion in Faculty Papers and Publications in Animal Science by an authorized administrator of DigitalCommons@University of Nebraska - Lincoln. 


\title{
Direct and correlated responses to two-stage selection for ovulation rate and number of fully formed pigs at birth in swine ${ }^{1}$
}

\author{
A. Ruíz-Flores and R. K. Johnson ${ }^{2,3}$ \\ Department of Animal Science, University of Nebraska, Lincoln 68583-0908
}

\begin{abstract}
Our objectives were to estimate responses and genetic parameters for ovulation rate, number of fully formed pigs at birth, and other production traits following two-stage selection for increased ovulation rate and number of fully formed pigs. Eight generations of selection were practiced in each of two lines. One selection line was derived from a line that previously selected eight generations for an index to increase ovulation rate and embryonic survival (the IOL pigs). The other selection line was derived from the unselected control line of the index selection experiment (the COL pigs). The control line (C) was continued with random selection. Due to previous selection, Line IOL had greater ovulation rate $(4.24 \pm 0.38$ and $4.14 \pm$ 0.29 ova $)$ and litter size (1.97 \pm 0.39 and $1.06 \pm 0.38$ pigs) at Generation 0 of two-stage selection than did Lines COL and C. In Stage 1, all gilts from 50\% of the largest litters were retained. Approximately 50\%
\end{abstract}

of them were selected for ovulation rate in Stage 2 . Gilts selected for ovulation rate were mated to boars selected from the upper one-third of the litters for litter size. At Generations 7 and 8, differences in mean EBV for ovulation rate and litter size between Lines IOL and $\mathrm{C}$ were $6.20 \pm 0.29$ ova and $4.66 \pm 0.38$ pigs; differences between Lines COL and $\mathrm{C}$ were $2.26 \pm 0.29$ ova and $2.79 \pm 0.39$ pigs; and differences between Lines IOL and COL were $3.94 \pm 0.26$ ova and $1.86 \pm 0.39$ pigs. Regressions of line mean EBV on generation number were $0.27 \pm 0.07$ ova and $0.35 \pm 0.06$ pigs in Line IOL; $0.30 \pm 0.06$ ova and $0.29 \pm 0.05$ pigs in Line COL; and $0.01 \pm 0.07$ ova and $0.02 \pm 0.05$ pigs in Line C. Correlated responses were decreased age at puberty and increased number of pigs born alive, number of mummified pigs, prenatal loss, and individual and litter birth weight. Two-stage selection for ovulation rate and number of pigs per litter is a promising procedure to improve litter size in swine.

Key Words: Litter Size, Ovulation Rate, Pigs, Selection

(C2001 American Society of Animal Science. All rights reserved.

J. Anim. Sci. 2001. 79:2286-2297

\section{Introduction}

Several authors have predicted greater response in litter size from selection for indexes of component traits than from direct selection for litter size in swine (Johnson et al., 1984; Bennett and Leymaster, 1989, 1990a), rabbits (Blasco et al., 1993), and mice (Clutter et al., 1990; Ribeiro et al., 1997a,b). Johnson et al. (1984) developed a selection index for litter size based on ovulation rate and embryonic survival. In their model, the product of ovulation rate and embryonic survival determines litter size. Alternatively, Bennett and Leymaster $(1989 ; 1990 a)$ developed a mathematical model for litter

\footnotetext{
${ }^{1}$ Published as paper no. 13098, Journal Ser., Nebraska Agric. Res. Div., University of Nebraska, Lincoln 68586-0908.

${ }^{2}$ Current address: Dept. de Zootecnia, Universidad Autónoma Chapingo, Chapingo, Edo. De Méx. CP 56230, Mexico.

${ }^{3}$ Correspondence: A218 Animal Science Department (phone: 402/ 472-6404; fax: 402/472-6362; E-mail: rjohnson5@unl.edu).

Received August 24, 2000.

Accepted April 6, 2001.
}

size integrating ovulation rate, potential embryonic viability, uterine capacity, and their interaction. In this model, litter size is determined by the most limiting factor of the number of potentially viable embryos and uterine capacity. In simulated selection, Bennett and Leymaster (1990b) found that indexes of ovulation rate and uterine capacity resulted in $37 \%$ greater response in litter size than direct selection for litter size.

In populations selected for increased ovulation rate, the number of fully formed pigs at birth is expected to more closely represent uterine capacity than in unselected populations. In populations with increased ovulation rate, selected gilts are expected to have ovulation rate and a subsequent number of potentially viable embryos exceeding uterine capacity. This experiment tests the hypothesis that selection with emphasis on ovulation rate in a first stage and the number of fully formed pigs in a second stage causes litter size to increase. The objective here is to quantify direct and correlated responses in ovulation rate, number of fully formed pigs at birth, and other production traits to two-stage selection for ovulation rate and number of fully formed pigs at birth. 


\section{Material and Methods}

\section{Population}

Pigs were from three genetic lines generated from a composite population whose origin and development were described by Neal et al. (1989). This population had two lines, one selected eight generations for an index of ovulation rate and embryonic survival and the other a randomly selected control. Two-stage selection was practiced in two lines derived from the index experiment. Line IOL was derived from the index selection line and Line COL was derived from the control line. The control line $(\mathbf{C})$ was maintained with random selection. (The letters $I$ and $C$ in the acronyms represent the lines of origin, index and control, respectively, and the letters $O L$ represents two-stage selection for ovulation rate and litter size.)

After producing their first litter in Generation 8 of the index selection experiment, selected Index line sows were mated to selected Index line boars for their second litter. A total of 42 litters by 18 sires were born. Twostage selection was initiated in the progeny by selecting two boars, a breeder and an alternate from each of the 15 largest litters, and all gilts from the 18 largest litters. These selected progeny were considered Generation 1 because they were selected on their dam's litter size, and the dam's records were considered Generation 0.

Lines $\mathrm{C}$ and COL were generated from the Generation 8 animals of the control line. As in the Index line, sows were mated to control boars for second litters. A total of 36 litters by 15 sires were produced. One son of each boar and one or two gilts from each litter were randomly selected for the control line, C. Two sons, a breeder and an alternate, were selected from the 15 largest litters, and all remaining gilts from the 20 largest litters were selected for Line COL. These pigs were Generation 1 of lines C and COL, respectively, and their dam's records were considered Generation 0 .

\section{Selection Criteria}

Lines IOL and COL underwent eight generations of two-stage selection. In Stage 1, all gilts born in 50\% of the litters with the greatest number of fully formed pigs at birth were retained. Approximately 100 gilts in each selection line were retained in the first stage. Laparotomy was subsequently performed on these gilts at their second estrus, the first estrus after pubertal estrus, to measure ovulation rate by counting number of corpora lutea. Approximately 50\% of these gilts were selected on ovulation rate in Stage 2. Boars in each line were selected from the 15 highest ranking litters for litter size. Two boars, a breeder and an alternate, were selected from each litter. In Line $\mathrm{C}$, at least one gilt per litter and one boar per half-sib family were randomly selected. Approximately 50 gilts of each line were selected each generation to obtain approximately 40 litters. Full- and half-sib couplings were avoided, otherwise matings were at random.

\section{Management of Pigs}

Pigs were managed in total confinement throughout their lives. When possible, pigs were cross-fostered within and across lines no later than $48 \mathrm{~h}$ after birth to reduce variation in number of pigs nursed by sows. Because of the timing of litters, it was not possible to completely standardize number nursed per dam. After fostering, $13 \%$ of the litters had eight or fewer pigs, and $20 \%$ of them still had 14 or more pigs. Traits measured at weaning were adjusted for variation in number of cohorts after standardization. It is not believed that variation in the numbers of pigs that the sows nursed affected estimates of responses to selection.

Weaning age was $28 \mathrm{~d}$ through the third generation, $22 \mathrm{~d}$ for the fourth generation, and 10 to $12 \mathrm{~d}$ for the last five generations. At weaning, pigs were allocated into environmentally controlled nursery rooms, where they remained to approximately $56 \mathrm{~d}$ of age. Then they were moved to naturally ventilated buildings with 10 pigs per pen. Boars and gilts were penned separately.

Generations were discrete; generation interval was $1 \mathrm{yr}$. Estrus detection in gilts began when the oldest gilts in the pen reached $125 \mathrm{~d}$ of age. Laparotomy was performed 7 to $14 \mathrm{~d}$ after gilts expressed their second estrus. Gilts averaged approximately $250 \mathrm{~d}$ of age when mated. Gilts were mated each day that they were in estrus and were placed in stalls for the gestation period.

During the growing period, pigs were allowed ad libitum access to corn-soybean based diets until they were approximately $180 \mathrm{~d}$ of age (gilts) or $160 \mathrm{~d}$ of age (boars). Thereafter until mating, they were given approximately $2.3 \mathrm{~kg}$ of feed per day. Pigs received a diet with $22.7 \% \mathrm{CP}$ in the nursery until attaining body weights of approximately $12 \mathrm{~kg}$ and then received a diet with $18.9 \% \mathrm{CP}$ to $56 \mathrm{~d}$ of age. Diets with $16.2 \% \mathrm{CP}$ were fed to pigs from $56 \mathrm{~d}$ of age to approximately $55-\mathrm{kg}$ body weights and then a $14 \% \mathrm{CP}$ diet was fed until mating age. During the gestation period until the last $14 \mathrm{~d}$, gilts were given $2.1 \mathrm{~kg}$ of feed per day. They received $2.5 \mathrm{~kg}$ per day during the last $14 \mathrm{~d}$. Gestation diets had $11.5 \% \mathrm{CP}$. Sows were allowed ad libitum access to diets containing $13.2 \% \mathrm{CP}$ during lactation. The ME in diets ranged from $3.19 \mathrm{Mcal} / \mathrm{kg}$ for gestation diets to 3.44 $\mathrm{Mcal} / \mathrm{kg}$ for nursery diets.

\section{Traits}

Number of corpora lutea at second estrus in gilts of lines IOL and COL was recorded in all but the third generation. In Line $\mathrm{C}$ gilts, ovulation rate was recorded only in the last four generations. Prenatal loss was calculated as the difference between ovulation rate and number of fully formed pigs at birth. Most gilts were mated at their third or fourth estrus, whereas ovulation rate at second estrus was recorded. Johnson et al. (1984) found an increase of 0.4 corpus luteum from second to third estrus in gilts of a line selected for increased ovulation rate. Thus, actual prenatal loss may have 
been more than estimated, but line differences are expected to be unbiased.

Number of pigs born alive, number of stillborn pigs, number of mummified pigs, and individual and litter birth weight were recorded at birth. Mummified pigs were not considered in litter birth weight, but stillborn pigs were included. Nurse dam for all pigs transferred to another litter was recorded. Number of pigs weaned and litter weaning weight were analyzed as traits of the nurse dam. Litter weaning weight was calculated as the sum of weights of all pigs raised by the sow. Individual weaning weight was considered a trait of the pig.

Age at puberty was recorded when the gilt first stood immobile to back pressure in presence of a boar. Gilts were weighed on average at $125 \mathrm{~d}$ of age, and both boars and gilts were weighed at approximately $178 \mathrm{~d}$ of age. Backfat was measured with a sonoray instrument (Renco Lean-Meter, Renco Corporation, Minneapolis, MN) during the first six generations and an A-Scan Plus Series 600 (Sonic Industries, Hatboro, PA) the last two generations. Backfat was recorded when average weight of pigs in the pen was approximately $95 \mathrm{~kg}$.

Ovulation rate, prenatal loss, age at puberty, and 125-d weight were not recorded in Generation 3 when unique management procedures were followed to improve herd health; thus these traits were measured in seven generations. Backfat and 178-d weight were recorded in eight generations. The litter traits were recorded in nine generations because base generation pigs were selected on the litter size record of their dam.

\section{Data Analysis}

Means and standard deviations for line-generation subclasses were obtained using the GLM procedures of SAS (SAS Inst. Inc., Cary, NC). The fixed models included line, generation, and their interaction. In addition, the models for pig weights at birth, weaning, and $178 \mathrm{~d}$ and backfat included the effect of sex of the animal. Models for pig and litter weaning weights included also the linear effects of number of pigs after transfer and weaning age. Models for 125-d and 178-d weights included both linear and quadratic effects of age at weighing. The model for backfat included the linear effect of weight.

Genetic parameters and direct and correlated responses were estimated with an animal model using the MTDFREML programs described by Boldman et al. (1995). Depending on the trait, models (see Table 1) were derived from the following linear animal model (Henderson, 1984):

$$
\mathbf{y}=\mathrm{X} \boldsymbol{\beta}+\mathrm{Z}_{\mathrm{d}} \mathbf{a}_{\mathrm{d}}+\mathrm{Z}_{\mathrm{m}} \mathbf{a}_{\mathrm{m}}+\mathrm{W} \mathbf{c}+\mathbf{e}
$$

where $\mathbf{y}$ represents the vector of observations; $X, Z_{d}$, $\mathrm{Z}_{\mathrm{m}}$, and $\mathrm{W}$ are known incidence matrices; $\beta$ represents the vector of fixed effects (i.e., generation and sex depending on trait); $\mathbf{a}_{\mathrm{d}}$ is the vector of random additive direct genetic effects; $\mathbf{a}_{\mathrm{m}}$ is the vector of random additive maternal genetic effects; $\mathbf{c}$ is the vector of random common environmental effect on animals born in the same litter; and $\mathbf{e}$ is the vector of random residual effects. Means and variances of variables are as follows:

$$
\begin{aligned}
& \mathrm{E}(\mathrm{y})=\mathrm{X} \beta \quad \mathrm{E}\left[\begin{array}{l}
\mathrm{a}_{\mathrm{d}} \\
\mathrm{a}_{\mathrm{m}} \\
\mathrm{c} \\
\mathrm{e}
\end{array}\right]=\left[\begin{array}{l}
0 \\
0 \\
0 \\
0
\end{array}\right] \\
& \mathrm{V}\left[\begin{array}{l}
\mathrm{a}_{\mathrm{d}} \\
\mathrm{a}_{\mathrm{m}} \\
\mathrm{c} \\
\mathrm{e}
\end{array}\right]=\left[\begin{array}{crc}
\mathrm{G}_{\mathrm{d}} \otimes \mathrm{A} & \mathrm{G}_{\mathrm{dm}} \otimes \mathrm{A} 0 & 0 \\
& \mathrm{G}_{\mathrm{m}} \otimes \mathrm{A} 0 & 0 \\
& \mathrm{D}_{0} \otimes \mathrm{I} & 0 \\
\text { Symmetric } & 0 & \mathrm{R}_{0} \otimes \mathrm{I}
\end{array}\right]
\end{aligned}
$$

where $\otimes$ denotes a direct product operation; $G_{d}, G_{m}$, $\mathrm{G}_{\mathrm{dm}}, \mathrm{D}_{0}$, and $\mathrm{R}_{0}$ are additive direct, additive maternal, additive direct by additive maternal, common litter of birth permanent environmental, and residual variance matrices, respectively, with order equal to the number of traits in the analysis; $A$ is the numerator relationship matrix; and I is an identity matrix of appropriate order. The presence of the maternal genetic and common environmental effects depended on the trait (Table 1).

All traits were first analyzed with a single-trait model to obtain initial estimates of variance components and to determine which effects to include in the final model. Univariate analyses were performed with a MTDFREML version that allowed estimation of the SE of heritability by using the average information matrix. Therefore, all SE for heritability estimates reported are from univariate analyses.

Then ovulation rate and number of fully formed pigs per litter were analyzed together. Afterwards, threetrait analyses were performed. Each three-trait analysis included ovulation rate, number of fully formed pigs, and 1 of the remaining 13 traits, each entered one at a time. Because selection was on ovulation rate and number of fully formed pigs, this approach produced unbiased estimates of responses (Sorensen and Johansson, 1992).

Estimates of variance components at convergence from the ovulation rate-fully formed pigs two-trait analysis were held constant in the three-trait analyses to avoid multiple estimates of parameters for ovulation rate and fully formed pigs. Variance components, heritabilities, genetic correlations, and estimated breeding values (EBV) were obtained from three-trait analyses. The convergence criterion varied from $1.0 \times 10^{-6}$ to 1.0 $\times 10^{-10}$. Analyses terminated when the same values of -2 log likelihood, estimates of variance components, and genetic parameters at convergence occurred in two independent restarts. All analyses reached this point.

Common litter and additive maternal genetic random effects were tested using the likelihood ratio test (Kendall and Stuart, 1979). The $-2 \cdot \log$ likelihood of the complete model and the submodel were obtained at conver- 
Two-stage selection for litter size in pigs

Table 1. Models used to estimate genetic parameters and genetic responses to selection ${ }^{\mathrm{a}}$

\begin{tabular}{llll}
\hline \hline Trait & Fixed effects & Random effects & Covariates \\
\hline OR & Generation & Animal & - \\
FF & Generation & Animal & - \\
BA & Generation & Animal & - \\
M & Generation & Animal & - \\
SB & Generation & Animal & - \\
BW & Generation, sex & Animal, maternal & - \\
LBW & Generation & Animal, maternal & Weaning age (L), number \\
IWW & Generation, sex & Animal, maternal, & after transfer (L) \\
& & common litter & Weaning age (L), number \\
LWW & Generation & Animal & after transfer (L) \\
& & & - \\
NW & Generation & Animal & - \\
PL & Generation & Animal & Ane at weighing (L and Q) \\
AP & Generation & Animal & Age at weighing (L and Q) \\
W1 & Generation & Animal, maternal & W2 \\
W2 & Generation, sex & Animal & Animal \\
BF & Generation, sex & And & \\
\hline
\end{tabular}

${ }^{\mathrm{a}} \mathrm{OR}=$ ovulation rate, $\mathrm{FF}=$ number of fully formed pigs at birth, $\mathrm{BA}=$ number of pigs born alive, $\mathrm{M}=$ number of mummified pigs, $\mathrm{SB}=$ number of stillborn pigs, BW = individual birth weight, LBW = litter birth weight, IWW = individual weaning weight, LWW = litter weaning weight, $\mathrm{NW}=$ number of pigs weaned, $\mathrm{PL}=$ prenatal loss, $\mathrm{AP}=$ age at puberty, $\mathrm{W} 1=$ weight at $125 \mathrm{~d}$, W2 = weight at $178 \mathrm{~d}, \mathrm{BF}=$ backfat, $\mathrm{L}=$ linear, and $\mathrm{Q}=$ quadratic.

gence. The ratio $-2\left(\log \Lambda_{\mathrm{i}}-\Lambda_{\mathrm{j}}\right)$, where $\Lambda$ is the value of the likelihood function for the model at convergence, is asymptotically distributed as chi-square with degrees of freedom equal to the difference in the number of parameters between the alternative models. The additive maternal genetic effect was included in the models for pig weights at birth, weaning, and $125 \mathrm{~d}$ and for litter birth weight. The common litter of birth effect was included in the model for pig weaning weight.

The method described by Johnson et al. (1999) was used to estimate direct and correlated responses to selection using linear orthogonal contrasts of EBV (â). A vector of coefficients (k) was generated for each traitline combination. Contrasts were constructed to estimate the linear regression of â on generation number.

The $\mathbf{k}$ for traits recorded in eight generations were obtained by dividing each element in the vector of orthogonal coefficients, $c^{\prime}=[-7,-5,-3,-1,1,3,5$, and 7], by the number of observations in the corresponding line-generation subclass. For those traits recorded in nine generations, the vector of orthogonal coefficients was $\mathrm{c}^{\prime}=[-4,-3,-2,-1,0,1,2,3$, and 4$]$. For ovulation rate, prenatal loss, age at puberty, and 125-d weight with empty subclasses, Generation 3 for all the lines and through Generation 3 for line C, the EBV used to estimate the regression coefficients were those for gilts with a record for number of fully formed pigs. Then the $\mathbf{k}$ were entered into MTDFREML at convergence in the three-trait analyses and one more iteration to estimate the linear contrasts of the â and their SE was performed. Regression coefficient estimates for ovulation rate and number of fully formed pigs were obtained from the bivariate analysis.

Regression coefficients were calculated as $2 \mathbf{k}^{\prime} \hat{a} / \mathbf{c}^{\prime} \mathbf{c}$, for traits recorded in eight generations, and as $\mathbf{k}^{\prime} \hat{a} / \mathbf{c}^{\prime} \mathbf{c}$ for those recorded in nine generations. The variance of $\mathbf{k}^{\prime}$ â was calculated as $\mathrm{V}\left(\mathbf{k}^{\prime} \hat{a}\right)=\mathbf{k}^{\prime} \mathbf{L}^{22} \mathbf{k}$, where $\mathbf{L}^{22}$ is the animal-by-animal part of the inverse of the coefficient matrix from the mixed-model equations at convergence for estimation of the variance components. Standard errors of regression coefficients were calculated as $\left[\mathrm{V}\left(\mathbf{k}^{\prime} \mathbf{a}\right)\right]^{0.5} / \mathbf{c}^{\prime} \mathbf{c}$. Significance of regressions was determined with a $t$-test with degrees of freedom equal to $\mathrm{g}$ -2 , equivalent to the degrees of freedom in the test of regression of $\mathrm{g}$ means on generation number. Regressions within each line and the difference between select and control lines were estimated.

Contrasts of differences in line mean EBV for ovulation rate and number of fully formed pigs at Generations 0,7 , and 8 were accomplished in a manner similar to that described above. These contrasts were of EBV from the bivariate analysis.

Inbreeding coefficients were obtained from MTDFREML analyses. They were averaged by linegeneration for pigs with a record for birth weight.

\section{Results}

\section{Phenotypic Means and Standard Deviations}

Line by generation phenotypic means are given in Tables 2 and 3. Line IOL had greater mean for ovulation rate (4.4 ova) at Generation 1 and number of fully formed pigs (3.2 pigs) at Generation 0 than lines COL and C. Means for traits measured at birth in Generation 0 were from second-parity sows. Mean number of fully formed pigs in the first-parity litter by these same sows was approximately two pigs less.

In Lines IOL and COL, the increase in mean ovulation rate and number of fully formed pigs was accompa- 
nied by increased number of stillborn and mummified pigs at birth. Means for number of live pigs per litter at birth increased in both selection lines. Line $\mathrm{C}$ means remained relatively stable throughout the experiment.

\section{Inbreeding}

Means for inbreeding by line generation for pigs with a record for birth weight are presented in Table 4. At Generation 0 , the difference in inbreeding between line IOL and lines COL and C was $1.6 \%$. The increase in inbreeding per generation was $1.29 \pm 0.04 \%$ in Line IOL, $0.84 \pm 0.16 \%$ in Line COL, and $0.75 \pm 0.03 \%$ in Line C. Rates of inbreeding during two-stage selection were expected to be equal in Lines IOL and COL. Previous selection in the index line, the origin of Line IOL, caused inbreeding to be greater at Generation 0 in IOL than in COL. Although not intended, subsequent selection in IOL apparently was for more closely related individuals than in COL. This occurred because litter size, not ovulation rate, was the most limiting trait in Line IOL, which had high ovulation rate due to previous selection. Thus, there was a tendency to select more gilts from large litters and to select from fewer litters than in Line COL, for which the traits were more in balance at Generation 0 .

\section{Genetic Parameters}

REML estimates of genetic and phenotypic correlations and additive direct $\left(\mathrm{h}_{\mathrm{d}}^{2}\right)$ and additive maternal $\left(\mathrm{h}_{\mathrm{m}}^{2}\right)$ heritabilities are presented in Table 5 . Differences between three-trait and univariate (not presented) estimates of heritability ranged from 0 to 0.05 for most traits. The maximum difference was for prenatal loss, for which heritability estimates were 0.30 and 0.12 in univariate and three-trait analyses, respectively.

The estimate of the genetic correlation between ovulation rate and number of fully formed pigs was 0.52.

Table 2. Number of observations (n) and unadjusted phenotypic means for ovulation rate (ova), number of fully formed pigs, and prenatal loss

(ova-fully formed pigs) by line generation

\begin{tabular}{|c|c|c|c|c|c|c|}
\hline \multirow[b]{3}{*}{ Generation } & \multicolumn{6}{|c|}{ Selection line $^{\mathrm{a}}$} \\
\hline & \multicolumn{2}{|c|}{ IOL } & \multicolumn{2}{|c|}{ COL } & \multicolumn{2}{|c|}{$\mathrm{C}$} \\
\hline & $\mathrm{n}$ & Mean & $\mathrm{n}$ & Mean & $\mathrm{n}$ & Mean \\
\hline \multicolumn{7}{|c|}{ Ovulation rate } \\
\hline 1 & 57 & 17.1 & 66 & 12.7 & 66 & 12.7 \\
\hline $2^{\mathrm{b}}$ & 101 & 17.3 & 92 & 13.0 & - & - \\
\hline $3^{\mathrm{b}}$ & 84 & 17.4 & 96 & 13.3 & - & - \\
\hline $4^{\mathrm{c}}$ & - & - & - & - & - & - \\
\hline 5 & 83 & 17.0 & 92 & 13.7 & 35 & 12.5 \\
\hline 6 & 96 & 18.5 & 88 & 14.2 & 52 & 13.0 \\
\hline 7 & 87 & 18.4 & 97 & 14.7 & 41 & 12.3 \\
\hline 8 & 90 & 19.0 & 99 & 15.1 & 51 & 12.9 \\
\hline \multicolumn{7}{|c|}{ Number of fully formed pigs } \\
\hline $0^{\mathrm{d}}$ & 42 & $13.4(11.3)^{\mathrm{d}}$ & 36 & $9.8(8.1)^{\mathrm{d}}$ & 36 & \\
\hline $1^{\mathrm{e}}$ & 44 & 11.1 & 38 & 10.2 & 41 & 9.4 \\
\hline 2 & 52 & 11.8 & 56 & 10.3 & 36 & 9.0 \\
\hline 3 & 43 & 12.2 & 45 & 9.8 & 36 & 9.3 \\
\hline 4 & 43 & 11.8 & 42 & 10.8 & 45 & 8.8 \\
\hline 5 & 41 & 12.7 & 43 & 10.4 & 39 & 8.5 \\
\hline 6 & 48 & 13.4 & 44 & 11.5 & 35 & 8.9 \\
\hline 7 & 43 & 13.4 & 45 & 11.8 & 37 & 9.6 \\
\hline 8 & 42 & 12.5 & 42 & 10.3 & 35 & 7.4 \\
\hline 1 & 44 & 6.5 & 38 & 3.4 & 38 & 3.4 \\
\hline 2 & 52 & 7.2 & 56 & 3.6 & - & - \\
\hline 3 & 43 & 6.3 & 44 & 4.9 & - & - \\
\hline $4^{\mathrm{b}}$ & - & - & - & - & - & - \\
\hline 5 & 41 & 5.8 & 43 & 4.6 & 29 & 4.2 \\
\hline 6 & 48 & 6.8 & 44 & 3.9 & 35 & 4.2 \\
\hline 7 & 43 & 6.7 & 45 & 4.4 & 34 & 2.8 \\
\hline 8 & 42 & 7.4 & 42 & 6.8 & 35 & 6.0 \\
\hline
\end{tabular}


Table 3. Number of observations (n) and unadjusted phenotypic means for number of pigs born alive, stillborn, and mummified by line generation

\begin{tabular}{|c|c|c|c|c|c|c|}
\hline \multirow[b]{3}{*}{ Generation } & \multicolumn{6}{|c|}{ Selection line ${ }^{a}$} \\
\hline & \multicolumn{2}{|c|}{ IOL } & \multicolumn{2}{|c|}{$\mathrm{COL}$} & \multicolumn{2}{|c|}{$\mathrm{C}$} \\
\hline & $\mathrm{n}$ & Mean & $\mathrm{n}$ & Mean & $\mathrm{n}$ & Mean \\
\hline \multicolumn{7}{|c|}{ Number of pigs born alive } \\
\hline 0 & 42 & $11.7(9.2)^{\mathrm{b}}$ & 36 & $9.1(7.6)^{b}$ & 36 & \\
\hline 1 & 44 & 9.6 & 38 & 9.7 & 41 & 9.0 \\
\hline 2 & 52 & 10.8 & 56 & 9.7 & 36 & 8.4 \\
\hline 3 & 43 & 10.2 & 45 & 9.1 & 36 & 8.9 \\
\hline 4 & 43 & 9.7 & 42 & 9.8 & 45 & 8.1 \\
\hline 5 & 41 & 11.0 & 43 & 9.6 & 39 & 8.1 \\
\hline 6 & 48 & 9.5 & 44 & 10.6 & 35 & 8.6 \\
\hline 7 & 43 & 11.1 & 45 & 10.8 & 37 & 9.0 \\
\hline 8 & 42 & 10.6 & 42 & 9.7 & 35 & 6.6 \\
\hline \multicolumn{7}{|c|}{ — Number of stillborn pigs } \\
\hline 0 & 42 & $1.7(2.0)^{\mathrm{b}}$ & 36 & $0.7(0.5)^{\mathrm{b}}$ & 36 & \\
\hline 1 & 44 & 1.4 & 38 & 0.5 & 41 & 0.3 \\
\hline 2 & 52 & 1.0 & 56 & 0.6 & 36 & 0.6 \\
\hline 3 & 43 & 2.0 & 45 & 0.7 & 36 & 0.4 \\
\hline 4 & 43 & 2.1 & 42 & 0.9 & 45 & 0.7 \\
\hline 5 & 41 & 1.7 & 43 & 0.8 & 39 & 0.4 \\
\hline 6 & 48 & 3.9 & 44 & 1.0 & 35 & 0.6 \\
\hline 7 & 43 & 2.3 & 45 & 1.1 & 37 & 0.6 \\
\hline 8 & 42 & 1.8 & 42 & 0.6 & 35 & 0.6 \\
\hline \multicolumn{7}{|c|}{ - Number of mummified pigs } \\
\hline 0 & 42 & $0.3(1.7)^{b}$ & 36 & $0.2(0.5)^{\mathrm{b}}$ & 36 & \\
\hline 1 & 44 & 0.3 & 38 & 0.2 & 41 & 0.2 \\
\hline 2 & 52 & 0.4 & 56 & 0.3 & 36 & 0.2 \\
\hline 3 & 43 & 0.5 & 45 & 0.4 & 36 & 0.1 \\
\hline 4 & 43 & 0.3 & 42 & 0.5 & 45 & 0.2 \\
\hline 5 & 41 & 0.5 & 43 & 0.6 & 39 & 0.2 \\
\hline 6 & 48 & 0.6 & 44 & 0.5 & 35 & 0.2 \\
\hline 7 & 43 & 0.5 & 45 & 0.5 & 37 & 0.2 \\
\hline 8 & 42 & 1.2 & 42 & 1.2 & 35 & 1.0 \\
\hline
\end{tabular}

Ovulation rate was highly and positively correlated with number of stillborn pigs $(0.62)$, prenatal loss $(0.83)$, and direct effects of birth weight (0.44) and litter birth weight (0.40). Ovulation rate was moderately nega- tively correlated ( -0.09 to -0.26$)$ with number of mummified pigs per litter, number weaned, litter weaning weight, backfat, direct effects of pig weaning weight, and maternal effects of birth weight and litter birth

Table 4. Mean, minimum (min), and maximum (max) inbreeding by line generation

\begin{tabular}{|c|c|c|c|c|c|c|c|c|c|}
\hline \multirow[b]{3}{*}{ Generation } & \multicolumn{9}{|c|}{ Selection line $\mathrm{e}^{\mathrm{a}}$} \\
\hline & \multicolumn{3}{|c|}{ IOL } & \multicolumn{3}{|c|}{$\mathrm{COL}$} & \multicolumn{3}{|c|}{$\mathrm{C}$} \\
\hline & Mean & Mix & Max & Mean & Min & Max & Mean & Min & Max \\
\hline 0 & 0.10 & 0.00 & 0.13 & 0.09 & 0.02 & 0.16 & 0.09 & 0.02 & 0.16 \\
\hline 1 & 0.12 & 0.09 & 0.17 & 0.08 & 0.05 & 0.17 & 0.09 & 0.05 & 0.15 \\
\hline 2 & 0.14 & 0.10 & 0.23 & 0.10 & 0.07 & 0.18 & 0.10 & 0.07 & 0.15 \\
\hline 3 & 0.14 & 0.11 & 0.20 & 0.11 & 0.08 & 0.23 & 0.11 & 0.08 & 0.24 \\
\hline 4 & 0.15 & 0.12 & 0.21 & 0.12 & 0.09 & 0.17 & 0.12 & 0.09 & 0.18 \\
\hline 5 & 0.17 & 0.02 & 0.22 & 0.14 & 0.02 & 0.23 & 0.12 & 0.09 & 0.18 \\
\hline 6 & 0.18 & 0.16 & 0.23 & 0.14 & 0.07 & 0.21 & 0.13 & 0.19 & 0.19 \\
\hline 7 & 0.19 & 0.17 & 0.24 & 0.15 & 0.11 & 0.26 & 0.14 & 0.12 & 0.12 \\
\hline 8 & 0.21 & 0.16 & 0.28 & 0.16 & 0.13 & 0.21 & 0.15 & 0.12 & 0.20 \\
\hline
\end{tabular}

${ }^{\mathrm{a}} \mathrm{IOL}=\mathrm{x}, \mathrm{COL}=\mathrm{x}, \mathrm{C}=\mathrm{x}$. 
Table 5. Estimates of heritabilities $\left(\mathrm{h}^{2}\right)$, phenotypic variances $\left(\sigma^{2}\right)$, genetic correlations $\left(\mathrm{r}_{\mathrm{g}}\right)$, and phenotypic correlations $\left(\mathrm{r}_{\mathrm{p}}\right)$ from three-trait analyses $\left(\mathrm{SE}\right.$ of $\mathrm{h}^{2}$ are from univariate analyses)

\begin{tabular}{|c|c|c|c|c|c|c|c|}
\hline \multirow[b]{2}{*}{ Trait $^{\mathrm{a}}$} & \multirow[b]{2}{*}{ Effect } & \multirow[b]{2}{*}{$\mathrm{h}^{2}$} & \multirow[b]{2}{*}{$\sigma^{2}$} & \multicolumn{2}{|c|}{$\mathrm{r}_{\mathrm{g}}$} & \multicolumn{2}{|c|}{$r_{p}$} \\
\hline & & & & OR & $\mathrm{FF}$ & OR & $\mathrm{FF}$ \\
\hline OR & $\mathrm{D}^{\mathrm{b}}$ & $0.42 \pm 0.06$ & 8.29 & - & - & - & - \\
\hline $\mathrm{FF}$ & $\mathrm{D}$ & $0.18 \pm 0.08$ & 10.76 & 0.52 & - & 0.16 & - \\
\hline $\mathrm{BA}$ & $\mathrm{D}$ & $0.23 \pm 0.06$ & 9.81 & 0.14 & 0.83 & 0.05 & 0.88 \\
\hline $\mathrm{M}$ & $\mathrm{D}$ & $0.17 \pm 0.05$ & 0.80 & -0.11 & 0.79 & 0.01 & -0.08 \\
\hline SB & D & $0.29 \pm 0.05$ & 2.54 & 0.62 & 0.20 & 0.23 & 0.33 \\
\hline $\mathrm{AP}, \mathrm{d}$ & $\mathrm{D}$ & $0.73 \pm 0.05$ & 675.36 & 0.07 & -0.41 & 0.07 & -0.12 \\
\hline $\mathrm{BF}, \mathrm{mm}$ & $\mathrm{D}$ & $0.49 \pm 0.04$ & 11.78 & -0.09 & 0.24 & -0.07 & 0.03 \\
\hline \multirow[t]{2}{*}{$\mathrm{BW}, \mathrm{kg}$} & $\mathrm{D}$ & $0.04 \pm 0.03$ & 0.09 & 0.44 & 0.22 & 0.11 & -0.05 \\
\hline & $\mathrm{M}^{\mathrm{c}}$ & $0.43 \pm 0.03$ & - & -0.26 & -0.95 & - & - \\
\hline \multirow[t]{2}{*}{ LBW, kg } & $\mathrm{D}$ & $0.30 \pm 0.12$ & 11.67 & 0.40 & 0.73 & 0.08 & 0.85 \\
\hline & M & $0.04 \pm 0.06$ & - & -0.14 & 0.19 & - & - \\
\hline LWW, kg & $\mathrm{D}$ & $0.16 \pm 0.05$ & 73.16 & -0.24 & 0.06 & -0.07 & -0.04 \\
\hline NW & $\mathrm{D}$ & $0.24 \pm 0.06$ & 4.54 & -0.22 & 0.62 & -0.11 & 0.34 \\
\hline PL & $\mathrm{D}$ & $0.12 \pm 0.09$ & 14.83 & 0.83 & -0.04 & 0.59 & -0.69 \\
\hline \multirow[t]{2}{*}{ W1, kg } & $\mathrm{D}$ & $0.36 \pm 0.10$ & 73.90 & 0.08 & -0.03 & 0.12 & 0.03 \\
\hline & M & $0.21 \pm 0.05$ & - & -0.01 & -0.37 & - & - \\
\hline $\mathrm{W} 2, \mathrm{~kg}$ & $\mathrm{D}$ & $0.58 \pm 0.04$ & 122.99 & 0.02 & -0.05 & 0.14 & 0.07 \\
\hline \multirow[t]{2}{*}{ IWW, kg } & $\mathrm{D}$ & $0.15 \pm 0.04$ & 0.80 & -0.18 & 0.18 & 0.06 & 0.04 \\
\hline & M & $0.25 \pm 0.03$ & - & 0.11 & -0.51 & - & - \\
\hline
\end{tabular}

${ }^{\mathrm{a}} \mathrm{OR}=$ ovulation rate, $\mathrm{FF}=$ number of fully formed pigs at birth, $\mathrm{BA}=$ number of pigs born alive, $\mathrm{M}=$ number of mummified pigs, $\mathrm{SB}=$ number of stillborn pigs, BW = individual birth weight, LBW = litter birth weight, IWW = individual weaning weight, LWW = litter weaning weight, NW = number of pigs weaned, $\mathrm{PL}=$ prenatal loss, $\mathrm{AP}=$ age at puberty, $\mathrm{W} 1=$ weight at $125 \mathrm{~d}, \mathrm{~W} 2=$ weight at $178 \mathrm{~d}, \mathrm{BF}=$ backfat.

${ }^{\mathrm{b}}$ Additive direct genetic effect.

${ }^{\mathrm{c} A d d i t i v e ~ m a t e r n a l ~ g e n e t i c ~ e f f e c t . ~}$

weight. The genetic correlations between ovulation rate and the rest of the traits were low ( 0.01 to 0.14 ). Genetic correlation estimates of number of fully formed pigs with number born alive, number of mummified pigs and number weaned per litter, and direct effects of litter birth weight were positive and high; but number of fully formed pigs was not genetically correlated with litter weaning weight, prenatal loss, 178-d weight, or direct effects of 125-d weight. However, number of fully formed pigs was negatively correlated $(-0.37$ to -0.95$)$ with age at puberty, and maternal effects of pig weights at birth, weaning, and $125 \mathrm{~d}$.

Estimates of phenotypic correlations were $0.16,0.23$, and 0.59 between ovulation rate and number of fully formed pigs, number of stillborn pigs, and prenatal loss, respectively. All other traits had correlations with ovulation rate close to zero. Number of fully formed pigs at birth was strongly phenotypically associated with number born alive and litter birth weight (positive), and with prenatal loss (negative) and positively correlated with number of stillborn pigs and number at weaning. Correlations between numbers of fully formed pigs and numbers of stillborn pigs and between numbers of fully formed pigs and numbers weaned were 0.33 and 0.34 , respectively. Correlations of number of fully formed pigs with other traits were close to zero.

\section{Regressions on Generations}

Regressions of mean EBV on generation number are in Table 6. Line $\mathrm{C}$ regressions were not significantly different from zero for any trait, whereas all Line IOL regressions were significant with the exception $(P>$ 0.10 ) of those for number weaned per litter, litter weaning weight, and backfat. Line COL regressions were significant for all traits except $(P>0.10)$ number of stillborn pigs, litter weaning weight, and pig weight at weaning, $125 \mathrm{~d}$, and $178 \mathrm{~d}$. Estimates of regression coefficients of line differences in mean EBV are presented in Table 7. Number of live pigs per litter increased at a slightly lower rate than number of fully formed pigs in both selection lines. Significant correlated responses included increases in number born alive, number of mumified pigs, prenatal loss, and pig and litter birth weights, and decreases in age at puberty. Inconsistent correlated responses were observed in number of stillborn pigs and number weaned, backfat, and pig weights at weaning, $125 \mathrm{~d}$, and $178 \mathrm{~d}$ (Tables 6 and 7).

\section{Discussion}

Success in genetic improvement of litter size in mice through direct selection on litter size in early experiments (Bakker et al., 1976; Joakimsen and Baker et al., 1977) led researchers to select directly on litter size in swine. However, results from a pioneer experiment were not encouraging as 10 generations of selection produced very little change (Bolet et al., 1989).

Cunningham et al. (1979) suggested that litter size could be regarded as a natural index of ovulation rate 
Table 6. Coefficients (b) and standard errors (SE) of regressions of mean estimated breeding value on generation number by trait and line

\begin{tabular}{|c|c|c|c|c|c|c|}
\hline \multirow[b]{3}{*}{ Trait $^{b}$} & \multicolumn{6}{|c|}{ Selection line $\mathrm{e}^{\mathrm{a}}$} \\
\hline & \multicolumn{2}{|c|}{ IOL } & \multicolumn{2}{|c|}{$\mathrm{COL}$} & \multicolumn{2}{|c|}{$\mathrm{C}$} \\
\hline & $\mathrm{b}$ & $\mathrm{SE}$ & $\mathrm{b}$ & $\mathrm{SE}$ & $\mathrm{b}$ & $\mathrm{SE}$ \\
\hline OR & $0.27^{* *}$ & 0.07 & $0.30 * *$ & 0.06 & 0.01 & 0.07 \\
\hline $\mathrm{FF}$ & $0.35^{* *}$ & 0.06 & $0.29^{* *}$ & 0.05 & 0.02 & 0.05 \\
\hline BA & $0.24^{* *}$ & 0.06 & $0.27 * *$ & 0.05 & 0.04 & 0.05 \\
\hline $\mathrm{M}$ & $0.04^{*}$ & 0.01 & $0.03^{*}$ & 0.01 & 0.00 & 0.01 \\
\hline SB & $0.10 * *$ & 0.03 & 0.03 & 0.02 & 0.01 & 0.02 \\
\hline $\mathrm{AP}, \mathrm{d}$ & $-2.37^{*}$ & 0.70 & $-2.03^{*}$ & 0.67 & -0.00 & 0.72 \\
\hline $\mathrm{BF}, \mathrm{mm}$ & 0.10 & 0.07 & $0.30 * *$ & 0.07 & -0.04 & 0.07 \\
\hline $\mathrm{BW}, \mathrm{kg}$ & $0.011^{* *}$ & 0.003 & $0.006 \dagger$ & 0.002 & -0.001 & 0.002 \\
\hline LBW, kg & $0.36^{* *}$ & 0.07 & $0.19 *$ & 0.06 & -0.03 & 0.06 \\
\hline LWW, kg & 0.01 & 0.15 & -0.04 & 0.14 & 0.06 & 0.13 \\
\hline NW & 0.07 & 0.04 & $0.15^{* *}$ & 0.03 & -0.01 & 0.03 \\
\hline PL & $0.15^{*}$ & 0.05 & $0.18^{* *}$ & 0.05 & 0.00 & 0.05 \\
\hline $\mathrm{W} 1, \mathrm{~kg}$ & $0.54^{*}$ & 0.20 & -0.12 & 0.19 & -0.08 & 0.18 \\
\hline $\mathrm{W} 2, \mathrm{~kg}$ & $1.12^{* *}$ & 0.24 & -0.13 & 0.23 & -0.18 & 0.24 \\
\hline IWW, kg & $0.03 \dagger$ & 0.01 & -0.00 & 0.01 & 0.00 & 0.01 \\
\hline
\end{tabular}

${ }^{\mathrm{a}} \mathrm{IOL}=\mathrm{x}, \mathrm{COL}=\mathrm{x}, \mathrm{C}=\mathrm{x}$.

${ }^{\mathrm{b}} \mathrm{OR}=$ ovulation rate (ova), $\mathrm{FF}=$ number of fully formed pigs at birth, $\mathrm{BA}=$ number of pigs born alive, $\mathrm{M}=$ number of mummified pigs, $\mathrm{SB}=$ number of stillborn pigs, $\mathrm{BW}=$ individual birth weight, $\mathrm{LBW}=$ litter birth weight, IWW = individual weaning weight, LWW = litter weaning weight, $\mathrm{NW}=$ number of pigs weaned, $\mathrm{PL}=$ prenatal loss (ova, embryo/fetuses), $\mathrm{AP}=$ age at puberty, $\mathrm{W} 1$ = weight at $125 \mathrm{~d}$, W2 = weight at $178 \mathrm{~d}, \mathrm{BF}=$ backfat.

$* P<0.05)$.

$* * P<0.01$

$\dagger P<0.10$.

and embryonic survival. Johnson et al. (1984) used this idea to develop a model in which litter size is determined by the product of ovulation rate and embryonic survival and an index was constructed to optimize weights on component traits. Selection on the optimum index was predicted to increase ovulation rate while restricting the decrease in embryonic survival and to increase litter size more than direct selection. An experiment to test this hypothesis began in 1981 in a Large White $\times$ Landrace composite population (Neal and Johnson, 1986). Selection for litter size was practiced using an index of ovulation rate and embryo/fetal survival to $50 \mathrm{~d}$ of gestation. At Generation 5, regressions of line differences on generation number were $0.57 \pm$ 0.11 ovum, $-1.3 \pm 1.0 \%$ survival to $50 \mathrm{~d}$, and $0.20 \pm 0.20$ fetus (Neal et al., 1989). These results suggested that index selection produced a better balance of genetic changes in components than did direct selection for either ovulation rate or litter size.

In developing this model, it was assumed that the genetic correlation between number of fetuses at $50 \mathrm{~d}$ of gestation and litter size was close to unity. However, results of Leymaster et al. (1986) and Christenson et al. (1987) confirmed that females with high ovulation rate continue to have fetal loss during late gestation. If such losses are genetically determined, index selection using prenatal survival to $50 \mathrm{~d}$ will produce less improvement in litter size than expected. Response in litter size after 11 generations of selection for increased index of ovulation rate and embyro survival followed by three generations of selection for litter size was approximately equal to what was expected with direct selection for litter size (Johnson et al., 1999). In mice, Kochera-Kirby and Nielsen (1993) reported similar responses after 21 generations of selection for increased index of ovulation rate and ova success (proportion of ova represented by pups born) in one line and direct selection on litter size in another line $(0.14 \pm 0.01$ and $0.16 \pm 0.06 \mathrm{pups} /$ generation, respectively).

An alternative model for litter size that integrates ovulation rate, potential embryonic viability, and uterine capacity was developed by Bennett and Leymaster (1989; 1990a,b). Simulating selection response, they showed that selection for a single component may not change litter size greatly (Bennett and Leymaster, 1989). In simulated selection for ovulation rate, uterine capacity, litter size, embryo survival, and index of ovulation rate with each of the other traits, Bennett and Leymaster (1990b) found that the two indexes of ovulation rate and uterine capacity each resulted in a $37 \%$ greater increase in litter size than direct selection for litter size. Indexes combining ovulation rate and either litter size or embryo survival increased litter size by $21 \%$ more than direct selection for litter size. Selection for ovulation size, uterine capacity, or embryo survival was 6,35 , and $79 \%$, respectively, less effective than direct selection for litter size. Experimental results of Johnson et al. (1984) and theoretical work of Bennett and Leymaster $(1989 ; 1990 a, b)$ were the basis for the two-stage selection experiment reported herein. The 
hypothesis was that two-stage selection for ovulation rate and number of fully formed pigs would effectively increase litter size according to the ovulation rate-uterine capacity model.

The estimate of heritability for ovulation rate of 0.42 \pm 0.06 is greater than the estimates of 0.17 (Neal et al., 1989) and 0.24 (Johnson et al., 1999) obtained from the index selection lines. But it is comparable to the estimates of $0.36 \pm 0.07$ to $0.52 \pm 0.10$ reported by Zimmerman and Cunningham (1975). The estimate of heritability for number of fully formed pigs was $0.18 \pm 0.08$, comparable to the estimate of 0.16 reported by Johnson et al. (1999). In a summary of results from studies with white European breeds, Haley et al. (1988) reported that the heritability of litter size is about 0.10 .

The estimate of the genetic correlation between ovulation rate and number of fully formed pigs was 0.52 . Johnson et al. (1999) reported an estimate of this correlation of 0.24. However, Haley and Lee (1992) reported an estimate of genetic correlation between ovulation rate and number of live pigs per litter of $0.98 \pm 0.11$. They interpreted this result to mean that genetic variation in ovulation rate is largely responsible for the genetic variation in number of live pigs, with no contribution from genetic variation in prenatal survival. Haley and Lee (1992) estimated a twofold increase in improvement of litter size by selecting for ovulation rate rather than litter size. Results reported herein and those of Bennett and Leymaster (1989) and Johnson et al. (1999) do not support this conclusion.
The genetic correlation between numbers of live and fully formed pigs was 0.83 . This is in agreement with the estimate of 0.92 in the review by Rothschild and Bidanel (1998). The estimate of genetic correlation between ovulation rate and prenatal loss was 0.83 . This is in close agreement with the genetic correlation between ovulation rate and embryo survival of -0.86 reported by Johnson et al. (1999). In mice, Clutter et al. (1990) reported estimates of 0.06 and 0.60 for the genetic correlation between embryo survival and ovulation rate, and between embryo survival and litter size, respectively.

The estimate of heritability for prenatal loss was 0.12 \pm 0.09 . Blasco et al. (1993) concluded that genetic variation in prenatal survival appears to explain most of the genetic variation in litter size in rabbits. In swine, Haley and Lee (1992) reported an estimate of zero for heritability of prenatal loss.

Genetic responses for number of fully formed pigs observed in Line IOL $(0.33 \pm 0.06 \mathrm{pig} /$ generation $)$ and Line COL $(0.27 \pm 0.06 \mathrm{pig} /$ generation $)$ were greater than the expected response to two-stage selection $(0.21 \mathrm{pig} /$ generation) calculated as described by Cunningham (1975). Expected response was calculated by adding the correlated response in litter size to selection on ovulation rate in the first stage ( $0.05 \mathrm{pig} / \mathrm{generation})$ to the direct response for litter size in the second stage of selection ( $0.16 \mathrm{pig} / \mathrm{generation})$ using selection intensities planned for this experiment and estimates of parameters from early generations of the index selection lines.

Table 7. Coefficients (b) and standard errors (SE) for regressions of mean estimated breeding value line differences on generation number

\begin{tabular}{|c|c|c|c|c|c|c|}
\hline \multirow[b]{3}{*}{ Trait $^{\mathrm{b}}$} & \multicolumn{6}{|c|}{ Selection line ${ }^{\mathrm{a}}$} \\
\hline & \multicolumn{2}{|c|}{ IOL-C } & \multicolumn{2}{|c|}{ COL-C } & \multicolumn{2}{|c|}{ IOL-COL } \\
\hline & $\mathrm{b}$ & $\mathrm{SE}$ & $\mathrm{b}$ & $\mathrm{SE}$ & $\mathrm{b}$ & $\mathrm{SE}$ \\
\hline OR & $0.26^{* *}$ & 0.07 & $0.29 * *$ & 0.06 & -0.04 & 0.05 \\
\hline $\mathrm{FF}$ & $0.33^{* *}$ & 0.06 & $0.27 * *$ & 0.06 & 0.06 & 0.06 \\
\hline $\mathrm{BA}$ & $0.21^{* *}$ & 0.06 & $0.24^{* *}$ & 0.06 & -0.03 & 0.06 \\
\hline $\mathrm{M}$ & $0.04^{*}$ & 0.01 & $0.03^{*}$ & 0.01 & 0.00 & 0.01 \\
\hline $\mathrm{SB}$ & $0.11^{* *}$ & 0.03 & 0.04 & 0.03 & $0.07^{*}$ & 0.03 \\
\hline $\mathrm{AP}, \mathrm{d}$ & $-2.37 * *$ & 0.62 & $-2.03^{*}$ & 0.55 & -0.35 & 0.51 \\
\hline $\mathrm{BF}, \mathrm{mm}$ & $0.14 \dagger$ & 0.06 & $0.34 * *$ & 0.06 & $-0.20^{*}$ & 0.06 \\
\hline BW, kg & $0.01^{* *}$ & 0.00 & $0.01 \dagger$ & 0.00 & 0.01 & 0.00 \\
\hline LBW, kg & $0.39^{* *}$ & 0.07 & $0.22^{*}$ & 0.07 & $0.16^{*}$ & 0.07 \\
\hline LWW, kg & -0.05 & 0.16 & -0.10 & 0.15 & 0.05 & 0.16 \\
\hline NW & $0.09 \dagger$ & 0.04 & $0.16^{* *}$ & 0.04 & -0.07 & 0.04 \\
\hline PL & $0.15^{*}$ & 0.05 & $0.18 * *$ & 0.05 & -0.03 & 0.04 \\
\hline W1, kg & $0.63^{*}$ & 0.21 & -0.05 & 0.20 & $0.68^{*}$ & 0.21 \\
\hline $\mathrm{W} 2, \mathrm{~kg}$ & $1.31^{* *}$ & 0.20 & 0.05 & 0.18 & $1.26^{* * *}$ & 0.18 \\
\hline IWW, kg & $0.03 \dagger$ & 0.01 & -0.01 & 0.01 & $0.04^{*}$ & 0.01 \\
\hline
\end{tabular}

${ }^{\mathrm{a}} \mathrm{IOL}=\mathrm{x}, \mathrm{COL}=\mathrm{x}, \mathrm{C}=\mathrm{x}$.

${ }^{\mathrm{b}} \mathrm{OR}=$ ovulation rate (ova), $\mathrm{FF}=$ number of fully formed pigs at birth, $\mathrm{BA}=$ number of pigs born alive, $\mathrm{M}=$ number of mummified pigs, $\mathrm{SB}=$ number of stillborn pigs, $\mathrm{BW}=$ individual birth weight, $\mathrm{LBW}=$ litter birth weight, IWW = individual weaning weight, LWW = litter weaning weight, $\mathrm{NW}=$ number of pigs weaned, $\mathrm{PL}=$ prenatal loss (ova, embryo/fetuses), $\mathrm{AP}=$ age at puberty, $\mathrm{W} 1=$ weight at $125 \mathrm{~d}$, W2 = weight at $178 \mathrm{~d}, \mathrm{BF}=$ backfat.

$* P<0.05$.

$* * P<0.01$

$\dagger P<0.10$. 
Table 8. Contrasts between line mean EBV for number of fully formed pigs at birth (FF) and ovulation rate (OR)

\begin{tabular}{|c|c|c|c|c|c|c|}
\hline \multirow[b]{2}{*}{ Generation } & \multicolumn{3}{|c|}{$\mathrm{FF}^{\mathrm{a}}$} & \multicolumn{3}{|c|}{$\mathrm{OR}^{\mathrm{a}}$} \\
\hline & IOL-C & COL-C & IOL-COL & IOL-C & COL-C & IOL-COL \\
\hline 0 & $1.97 \pm 0.39$ & $0.91 \pm 0.39$ & $1.06 \pm 0.38$ & & & \\
\hline 1 & & & & $4.24 \pm 0.38$ & $0.10 \pm 0.29$ & $4.14 \pm 0.29$ \\
\hline 7 & - & - & - & $6.20 \pm 0.29$ & $2.26 \pm 0.29$ & $3.94 \pm 0.26$ \\
\hline 8 & $4.66 \pm 0.38$ & $2.79 \pm 0.39$ & $1.86 \pm 0.39$ & - & - & - \\
\hline
\end{tabular}

In Line COL, number of fully formed pigs increased $97 \%$ as rapidly as ovulation rate. In Line IOL, number of fully formed pigs increased $130 \%$ as rapidly as ovulation rate. The control line from which Line COL was derived had no antecedents of selection, neither for component traits nor directly for litter size, whereas Line IOL already had increased ovulation rate and number of fully formed pigs, due to previous selection. Responses for ovulation rate, number of fully formed pigs and number born alive to two-stage selection were comparable in both selection lines (Table 6). This suggests that rate of change for ovulation rate and number of fully formed pigs was not dependent on mean genetic level of the line.

Differences between line mean EBV for number of fully formed pigs and ovulation rate at Generations 0 , 1,7 , and 8 are presented in Table 8 . The difference in mean EBV for ovulation rate and number of fully formed pigs between lines IOL and C increased from $4.24 \pm 0.38$ ova at Generation 1 and $1.97 \pm 0.39$ pigs at Generation 0 to $6.20 \pm 0.29$ ova at Generation 7 and $4.66 \pm 0.38$ pigs at Generation 8 . The difference in mean EBV for ovulation rate and number of fully formed pigs between Lines COL and C increased from $0.10 \pm 0.29$ ovum at Generation 1 and $0.91 \pm 0.39$ pig at Generation 0 to $2.26 \pm 0.26$ ova at Generation 7 and $2.79 \pm 0.39$ pigs at Generation 8. The difference in mean EBV between Lines IOL and COL for ovulation rate decreased slightly from $4.14 \pm 0.29$ ova at Generation 1 to $3.94 \pm$ 0.26 ova at Generation 7. The difference in mean EBV between Lines IOL and COL for number of fully formed pigs increased from $1.06 \pm 0.38$ pigs in Generation 0 to $1.86 \pm 0.39$ pigs at Generation 8. These comparisons suggest that, at Generation 0, uterine capacity was more limiting in Line IOL than in Line COL. Therefore, number of fully formed pigs may have been a better measurement of uterine capacity in Line IOL than in Line COL. Selection for litter size in Line IOL should have resulted in a greater increase in uterine capacity than selection for litter size in COL. A greater response in the most limiting component will cause the greatest increase in litter size (Bennett and Leymaster, 1989). These results confirm the simulation work of Bennett and Leymaster (1989), who predicted that changes in the component (ovulation rate or uterine capacity) with lesser mean will result in larger effects on litter size, and the results of their simulations (Bennett and Leymaster, 1990a) in which responses in litter size to index selection for ovulation rate and uterine capacity exceeded direct selection for litter size.

Estimated responses of ovulation rate and number of fully formed pigs per litter in selected lines were used in equations of Bennett and Leymaster (1989) to predict changes in prenatal survival and uterine capacity. The mean ovulation rate for the base generation in Lines $\mathrm{COL}$ and $\mathrm{C}$ was estimated as the unweighted average of all generations of Line $\mathrm{C}$ data. Means for ovulation rate in Line IOL for Generations 0 and 8 were predicted by adjusting this mean up and down with the estimated genetic response per generation. This procedure was chosen because using all generation means and estimates of genetic change gives more precise estimates than the point estimates from first and last generations. Given that estimated response $(0.01 \pm 0.07$ ovum/generation) for ovulation rate in Line $\mathrm{C}$ was not significant, mean ovulation rate for the base generation was assumed to be the same as at Generation 8. However, ovulation rate was measured at second estrus and most of the gilts became pregnant at third estrus. Therefore,

Table 9. Predicted means and standard deviations (SD) by line at Generations 0 and 7 for uterine capacity (UC) and prenatal survival (PS) using equations of Bennett and Leymaster (1989)

\begin{tabular}{|c|c|c|c|c|c|c|c|c|c|c|c|c|}
\hline \multirow{2}{*}{ Generation } & \multicolumn{6}{|c|}{ Means $^{\mathrm{a}}$} & \multicolumn{6}{|c|}{$\mathrm{SD}^{\mathrm{a}}$} \\
\hline & \multicolumn{2}{|c|}{ IOL } & \multicolumn{2}{|c|}{ COL } & \multicolumn{2}{|c|}{$\mathrm{C}$} & \multicolumn{2}{|c|}{ IOL } & \multicolumn{2}{|c|}{ COL } & \multicolumn{2}{|c|}{$\mathrm{C}$} \\
\hline 0 & 11.73 & 64.31 & 11.60 & 72.30 & 10.50 & 69.78 & 3.26 & 19.23 & 2.64 & 18.26 & 2.62 & 19.01 \\
\hline 7 & 16.26 & 72.18 & 15.59 & 75.26 & 10.50 & 69.78 & 3.85 & 18.42 & 3.13 & 16.85 & 2.62 & 19.01 \\
\hline
\end{tabular}

${ }^{\mathrm{a}} \mathrm{IOL}=\mathrm{x}, \mathrm{COL}=\mathrm{x}, \mathrm{C}=\mathrm{x}$. 
according to Johnson et al. (1984), 0.4 ovum was added to estimated mean ovulation rate to compensate this difference.

A similar procedure was used to estimate mean number of fully formed pigs per litter for the base and eighth generations. Except in calculating the unweighted mean number of fully formed pigs per litter, data of the base generation were not included because they were from second-parity sows.

Predicted means and standard deviations by line at Generations 0 and 7 for uterine capacity and prenatal survival are presented in Table 9. Uterine capacity increased more in Line IOL (4.53 pigs) than in Line COL (3.99 pigs). The increase in prenatal survival was also greater (7.87\%) in Line IOL than in Line COL (2.96\%). The change in uterine capacity relative to ovulation rate was greater in Line IOL than in Line COL. The changes in prenatal survival were determined by relative changes in ovulation rate and uterine capacity.

Cassady et al. (1999) reported that even though the genetic correlations between ovulation rate and plasma concentration of FSH at 58, 90, and $124 \mathrm{~d}$ of age were moderate to low, selection for increased plasma concentration of FSH can be used as an indirect selection criteria for ovulation rate. They found indirect selection was $93 \%$ as effective in changing ovulation rate as direct selection because selection for plasma concentration of FSH can be done in both sexes. In our experiment, twostage selection for ovulation rate and number of fully formed pigs was effective because litter size in gilts with increased ovulation rate was an effective measure of uterine capacity. However, this procedure still requires that laparotomy be used to record ovulation rate, an impractical procedure in most breeding herds. A strategy to improve litter size could be to select for uterine capacity through litter size in a first stage and on plasma concentration of FSH in a second stage, replacing the difficult task of measuring ovulation rate with the easier task of measuring plasma FSH.

\section{Implications}

Two-stage selection was effective in improving ovulation rate and litter size. Approximately $97 \%$ of the increase in ovulation rate was realized as an increase in the number of fully formed pigs in Line COL. And in a line that was previously selected for increased ovulation rate, litter size increased more rapidly than ovulation rate. Thus, two-stage selection can be used successfully to improve litter size in populations varying greatly in ovulation rate and litter size. Application of these procedures would be enhanced by a noninvasive procedure to record ovulation rate. Because the numbers of mummified and stillborn pigs increased along with increased numbers of fully formed pigs, selection criteria to increase litter size should include the number and(or) weight of live pigs.

\section{Literature Cited}

Bakker, H., J. H. Wallinga, and R. D. Politiek. 1976. Reproduction and body weight of mice after long term selection for litter size. In: Proc. 27th Annual Meeting Eur. Assoc. Anim. Prod., Zurich, Switzerland. p 19.

Bennett, G. L., and K. A. Leymaster. 1989. Integration of ovulation rate, potential embryonic viability and uterine capacity into a model of litter size in swine. J. Anim. Sci. 67:1230-1241.

Bennett, G. L., and K. A. Leymaster. 1990a. Genetic implications of a simulation model of litter size in swine based on ovulation rate, potential embryonic viability and uterine capacity: I. Genetic theory. J. Anim. Sci. 68:969-979.

Bennett, G. L., and K. A. Leymaster. 1990b. Genetic implications of a simulation model of litter size in swine based on ovulation rate, potential embryonic viability and uterine capacity: II. Simulated selection. J. Anim. Sci. 68:980-986.

Blasco, A., M. A. Santacreu, R. Thompson, and C. S. Haley. 1993. Estimates of genetic parameters for ovulation rate, prenatal survival, and litter size in rabbits from an elliptical experiment. Livest. Prod. Sci. 34:163-174.

Boldman, K. G., L. A. Kriese, L. D. Van Vleck, C. P. Van Tassell, and S. D. Kachman. 1995. A manual for use of MTDFREML (Draft). USDA, ARS, US Meat Animal Research Center, Clay Center, NE.

Bolet, G., L. Ollivier, and P. Dando. 1989. Sélection sur la prolificité chez le porc. I. Résultats d'une expérience de sélection sur onze générations. Genet. Sel. Evol. 21:93-106.

Cassady, J. P., R. K. Johnson, and J. J. Ford. 1999. Comparison of plasma FSH concentration in boars and gilts from lines selected for ovulation rate, embryonic survival and litter size and estimation of (co)variance components for FSH and ovulation rate. J. Anim. Sci. (In press).

Christenson, R. K., K. A. Leymaster, and L. D. Young. 1987. Justification of unilateral hysterectomy-ovariectomy as a model to evaluate uterine capacity in swine. J. Anim. Sci. 65:738-744.

Clutter, A. C., M. K. Nielsen, and R. K. Johnson. 1990. Alternative methods of selection for litter size in mice: I. Characterization of base population and development of methods. J. Anim. Sci. 68:3536-3542.

Cunningham, E. P. 1975. Multi-stage index selection. Theor. Appl. Genet. 46:55-61.

Cunningham, P. J., M. E. England, L. D. Young, and D. R. Zimmerman. 1979. Selection for ovulation rate in swine: Correlated response in litter size and weight. J. Anim. Sci. 48:509-516.

Haley, C. S., E. Avalos, and C. Smith. 1988. Selection for litter size in the pig. Anim. Breed. Abstr. 56:317-332.

Haley, C. S., and G. J. Lee. 1992. Genetic factors contributing to variation in litter size in British Large White gilts. Livest. Prod. Sci. 30:99-113.

Henderson, C. R. 1984. Applications of Linear Models in Animal Breeding. Guelph University Press, Guelph.

Joakimsen, O., and R. L. Baker. 1977. Selection for litter size in mice. Acta Agric. Scand. 27:301-318.

Johnson, R. K., M. K. Nielsen, and D. S. Casey. 1999. Responses in ovulation rate, embryonal survival, and litter traits in swine from 14 generations of selection to increase litter size. J. Anim. Sci. 77:541-557.

Johnson, R. K., D. R. Zimmerman, and R. J. Kittock. 1984. Selection for components of reproduction in swine. Livest. Prod. Sci. 11:541-558.

Kendall, M., and A. Stuart. 1979. The Advanced Theory of Statistics. vol. 2. Charles Griffin and Company Limited, High Wycombe, U.K.

Kochera-Kirby, Y., and M. K. Nielsen. 1993. Alternative methods of selection for litter size in mice: III. Response to 21 generations of selection. J. Anim. Sci. 71:571-578.

Leymaster, K. A., R. K. Christenson, and L. D. Young. 1986. A biological model to measure potential for litter size in swine. In: Proc. 
3rd World Congr. Genet. Appl. Livest. Prod., Lincoln, NE. pp 209-214.

Neal, S. M., and R. K. Johnson. 1986. Selection for components of litter size in swine: Genetic parameters and expected response. In: Proc. 3rd World Congr. Genet. Appl. Livest. Prod. Lincoln, NE. pp 228-233.

Neal, S. M., R. K. Johnson, and R. J. Kittok. 1989. Index selection for components of litter size in swine: Response to five generations of selection. J. Anim. Sci. 67:1933-1945.

Ribeiro, E. L. de A., M. K. Nielsen, G. L. Bennett, and K. A. Leymaster. 1997a. A simulation model including ovulation rate, potential embryonic viability, and uterine capacity to explain litter size in mice: I. Model development and implementation. J. Anim. Sci. 75:641-651.
Ribeiro, E. L. de A., M. K. Nielsen, K. A. Leymaster, and G. L. Bennett. 1997b. A simulation model including ovulation rate, potential embryonic viability, and uterine capacity to explain litter size in mice: II. Responses to alternative criteria of selection. J. Anim. Sci. 75:652-656.

Rothschild, M. F., and J. P. Bidanel. 1998. Biology and genetics of reproduction. In: M. F. Rothschild and A. Ruvinsky (ed.) The Genetics of the Pig. pp 313-343, CAB International, New York.

Sorensen, D. A., and K. Johansson. 1992. Estimation of direct and correlated responses to selection using univariate animal models. J. Anim. Sci. 70:2038-2044.

Zimmerman, D. R., and P. J. Cunningham. 1975. Selection for ovulation rate in swine: Population, procedures and ovulation response. J. Anim. Sci. 40:61-69. 